\title{
UČEBNA PRO VÝUKU KRIZOVÉHO MANAGEMENTU NA ZDRAVOTNĚ SOCIÁLNÍ FAKULTĚ
}

\author{
IX: 213-458, 2007 \\ ISSN 1212-4117 \\ Renata Havránková1, Miroslav Hromada ${ }^{2}$, Leoš Navráti1 ${ }^{1}$ \\ 1Jihočeská univerzita vČeských Budějovicích, Zdravotně sociální fakulta, katedra radiologie \\ a toxikologie \\ ${ }^{2}$ Jihočeská univerzita v Českých Budějovicích, Zdravotně sociální fakulta, technické oddělení
}

V posledních letech se stále častěji vyskytujî různá ohrožení obyvatelstva, na která musí být občané připraveni. Nemáme na mysli pouze živelní pohromy, které se vyskytují nejen ve světě, ale i v ČR (povodně, sucho, vichřice apod.), ale i teroristické útoky, průmyslové havárie, ekologická nebezpečí a další. S ohledem na globalizaci světa a snadnou dosažitelnost každého civilizovaného místa na zeměkouli nelze vyloučit teroristický útok ani na území České republiky. Proto je důležitá a aktuální kvalitní pŕṕprava odborníků v oblasti obrany, bezpečnosti a ochrany.

Problematika vzdělávání v oblasti Ochrany obyvatelstva je obsažena v materiálu Generálního ředitelství Hasičského záchranného sboru ČR čj. 1455/05 „Návrh optimalizace bezpečnostního systému České republiky “ a následném usnesení vlády ČR č. 1214 ze dne 21. zář́i 2005.

Kvalitní príprava studentů se zaměřením na problematiku ochrany obyvatelstva a krizového řízení je dnes nezbytným předpokladem pro odpovídající uplatnění po absolvování vysoké školy, a to jak po stránce teoretické, tak i praktické. Tento požadavek je možné splnit pouze odpovídající praktickou výukou. Proto byla na Zdravotně sociální fakultě Jihočeské univerzity $v$ rámci řešení projektu FRVŠ č. 295/2007 zřízena učebna pro výuku předmětů zaměřených na problematiku krizového managementu, která umožní získání praktických dovedností a rychlejší zapracování absolventů po nástupu do zaměstnání, at’ již v rámci orgánů státní správy a samosprávy, nebo ve složkách Integrovaného záchranného systému ČR, prípadně v rámci Armády České republiky.

Výuka $\mathrm{v}$ této učebně probíhá od zimního semestru akademického roku 2007/2008 ve všech oborech akreditovaných na Zdravotně sociální fakultě, ve kterých se vyučují předměty týkající se krizového řízení a ochrany obyvatelstva. Učebna bude také využívána $\mathrm{v}$ rámci celoživotního vzdělávání, které je určeno především pro př́slušníky Hasičského záchranného sboru a Policie ČR, ale i zaměstnance úřadů státní správy a samosprávy a bude $\mathrm{k}$ dispozici i dalším fakultám Jihočeské univerzity, pokud bude katedra radiologie a toxikologie výuku v dané problematice zabezpečovat.

Tato specializovaná učebna je vybavena 12 pracovními místy s počítači určenými pro studenty a 1 serverovým počítačem určeným pro vyučujícího. Samozrejmostí je připojení učebny $\mathrm{k}$ internetu.

$\mathrm{Na}$ každém počítači jsou nainstalovány speciální softwary - EMOFF a TEREX, které budou využity pro praktická cvičení v rámci výuky předmětů v oblasti krizového řízení. Jedná se o programy, které jsou již využívány v České republice $\mathrm{v}$ rámci státní správy a samosprávy. Výuku zajišt'ují přednášející, kteří jej využívají v rámci své každodenní činnosti. Svou kvalifikací a praktickými zkušenostmi v oblasti krizového managementu a ochrany obyvatelstva jsou tak schopni garantovat vysokou kvalitu výuky a pripravit studenty pro výkon jejich budoucího povolání.

Informační systém EMOFF (Emergency Office) pomáhá usnadnit a zefektivnit činnost v oblasti:

- analýzy nebezpečí a rizik;

- vyhodnocení bezpečnostních rizik;

- plánování, organizování, realizování a kontroly činností;

- shromažd'ování a vyhodnocování informací o organizacích, osobách, silách, technice a zdrojích pomoci pro zvládání krizových stavů;

- podpory řešení krizových stavů a mimořádných událostí. 
Systém podporuje součinnost více osob, organizací či orgánů s různou specializací a umožňuje připojení doprovodných informací - digitálně zpracované zákresy, obrázky, videozáznamy a další libovolné dokumenty. Zahrnuje i služby umožňující prípojení externích informačních systémů.

TEREX je nástrojem pro rychlou prognózu dopadů a následků působení nebezpečných látek nebo výbušných systémů, zejména při jejich kategorickém zneužití. Tento program umožňuje analýzy rizik plánování, výpočet prvních odhadů následků průmyslových havárií a výbuchů i následků působení otravných látek a zbraní hromadného ničení. Databáze obsahuje více než 120 látek s popisem jejich vlastností, zraňujících projevů a první pomoci.

Učebna je rovněž vybavena promítací technikou (dataprojektor, promítací plátno) a inter- aktivní tabulí. Vybavení učebny výrazným způsobem přispěje ke zkvalitnění výuky i po stránce didaktické.

Předpokládáme, že se v budoucnu zaměříme na řešení konkrétních mimořádných událostí, které se staly. Studenti je budou moci analyzovat, odhalit možné chyby, které se objevily při jejich řešení, a navrhnout lepší varianty řešení, které vzápětí budou moci v modelu ověřit. Ve spolupráci s Hasičským záchranným sborem Jihočeského kraje proto plánujeme vytvoření vlastní dokumentační databáze s ukázkami vybraných mimořádných událostí a krizových situací.

* Tento př́spěvek vznikl na základě podpory projektu FRV ̌̌ č. 295/2007.

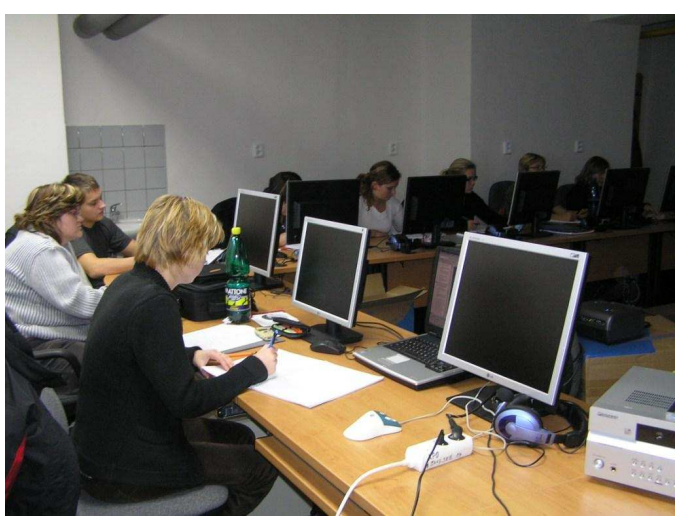

Učebna pro výuku krizového managementu

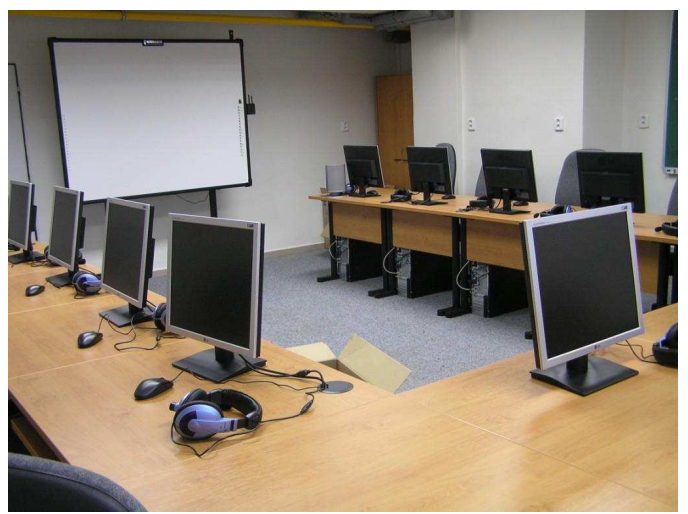

Renata Havránková et al. renka.havrankova@seznam.cz 